\title{
Konfigurasi Elite Selama Pandemi COVID-19 di Desa Jelgung Kabupaten Sampang
}

\author{
Endik Hidayat ${ }^{1}$, Aufa Izzudin Baihaqi ${ }^{2}$, Rustono Farady Marta ${ }^{3}$ \\ ${ }^{1}$ Universitas Pembangunan Nasional Veteran Jawa Timur \\ ${ }^{2}$ Universitas Pembangunan Nasional Veteran Jawa Timur \\ ${ }^{3}$ Universitas Bunda Mulia \\ E-mail: rmarta@bundamulia.ac.id
}

\begin{abstract}
Influential groups, source of power and the change of elites post-pandemic rises the social questions of the study. This research aims aims to discuss the dynamics of elite configuration during the COVID-19 pandemic in Jelgung Village Sampang Regency, Madura. Using Putnam's elite theory and Andrain's theory of sources of power, the research will be allocated in Jelgung Village, Sampang Regency uses a qualitative method with a case study research model. The data is collected through in-depth interview with informants relevant to the topic of the village elite. The results showed that the elite of the Jelgung village consisted of the government, religious leaders, health workers, champions or blater groups, military officers and retired soldiers, and business unit owners. It's also discovered a configuration that consists of shifting sources and channels of power during the COVID-19 pandemic towards the elite constellation of Jelgung Village due to their contribution, namely doctors, nurses, and midwives.
\end{abstract}

Keywords: Configuration, Elite Village, Power, Madura, COVID-19

\section{Pendahuluan}

Motif utama artikel ini adalah untuk mendapatkan suatu bentuk analisis dalam rangka mempelajari dinamika konfigurasi elite desa selama pandemi COVID-19. Fenomena dinamika kehidupan sosial dan politik pedesaan merupakan kompetisi yang menjadi faktor keputusan warga dalam menentukan individu yang influensial. Tulisan ini mengamati perilaku tokoh masyarakat desa dan aktor-aktor utama dalam interaksi sosial di pedesaan Madura. Lebih khusus tujuan artikel ini mengelaborasi tokoh manakah atau orang-orang mana saja yang menduduki stratafikasi sosial tinggi di tingkat desa. Varma (2010) mengatakan bahwa pada umumnya elite berasal dari kelas yang sama, yaitu orang-orang kaya dan pandai yang mempunyai kelebihan dalam matematika, bidang musik, karakter moral dan sebagainya. Pareto lebih lanjut membagi elite, yaitu pertama elite yang memerintah (governing elite) dan elite yang tidak memerintah (non-governing elite).

Pandemi COVID-19 tentunya memperkuat peran warga elite desa yang memitigasi pandemi. Data dari situs pemerintahan Sampang menunjukkan kelompok elite desa yang tanggap dalam kebijakan desa dalam rangka memutus rantai penyebaran virus. Aksi tanggap darurat Pemerintah Kabupaten Sampang meluncurkan kebijakan sebagai upaya mengantisipasi penyebaran virus Covid-19, melalui Surat Edaran (SE) Bupati Sampang nomor: 440/655/434.203/2020 tentang upaya pencegahan penularan Covid19. Respons awal pemerintah desa tentang SE Bupati Sampang adalah menyiapkan masker yang dibagikan gratis kepada masyarakat. Program terkait pengadaan masker di desa harus memanfaatkan industri kecil menengah (IKM) di desa masing-masing. Pemerintah desa juga bisa mengoptimalkan penggunaan dana desa (DD) untuk menanggulangi wabah penyakit Covid-19 (Basri, 2020). 
Pada situasi krisis dan tidak normal akibat pandemi, pemerintah desa seharusnya lebih gencar berkolaborasi dengan para elite desa dalam menyukseskan berbagai kebijakan penanggulangan COVID-19. Kelompok elite ini yang berpengaruh dalam pengambilan keputusan publik khususnya masyarakat pedesaan. Kolaborasi ini dapat terjalin secara digital untuk membantu pemerintah memutus rantai COVID-19. Digitalisasi kerja sama antar pemerintah desa dengan tokoh penting merupakan urgensi peningkatan efektivitas transmisi pesan kepada massa (Magfirah \& Saputra, 2021). Beberapa golongan elite tersebut adalah dari pihak pemerintah desa, tokoh agama, tokoh masyarakat, dan kalangan pengusaha kaya di desa. Jaringan komunikasi antar organisasi masyarakat menciptakan sebuah golongan masyarakat (Yusriyah et al., 2020). Munculnya golongan prioritas elite adalah wujud implementasi demokrasi elitis, massa dipandang sebagai pihak yang tidak perlu terlibat langsung dalam proses pengambilan keputusan. Karena rakyat dianggap tidak mampu dan tidak punya wewenang untuk menyelesaikan permasalahan-permasalahan pemerintah (Hardhiyanti \& Rasyid, 2018). Ideologi bahwa rakyat lebih baik apatis dan bijaksana untuk tidak menciptakan tindakan-tindakan yang merusak budaya, masyarakat, dan kebebasan juga ditekankan dalam tokoh elite tersebut (Muslim et al., 2015). Dengan demikian, peran masyarakat desa lebih kepada partisipasi ketika penyelenggaraan pemilihan kepala desa supaya dapat menyalurkan aspirasinya.

Pemerintah desa menggandeng kelompok elite yang turut serta terlibat dalam penanganan situasi pandemi COVID-19 wilayah Sampang. Oleh sebab itu, interaksi antar elite otomatis terjadi dan tidak mungkin dihindari. Interaksi akan mengundang sebuah identitas baru dalam wilayah Sampang (Lang et al., 2020). Pola interaksi antara elite desa bisa diamati dalam momentum situasi pandemi COVID-19 di desa Jelgung. Pola interaksi mencakup metode individu atau kelompok dalam menyesuaikan hubungan dengan kelompok lainnya. Pola interaksi dapat menjadi pedoman dalam penelitian ini untuk mengidentifikasi interaksi warga elite desa terhadap warganya (Vicari et al., 2020).

Pola interaksi elite terbagi menjadi tiga model, pertama pola kolusi yang menghasilkan konsentrasi kekuasaan tingkat desa. Kedua, pola relasi yang saling berhadapan secara antagonis dan nyaris tak terdamaikan. Ketiga, pola relasi kompromi antara sumber-sumber kekuasaan sehingga melahirkan perdamaian (Cahyono, 2005). Dua pola interaksi yang muncul antara elite desa. Pertama, muncul pola interaksi hegemonik yang terjadi ketika pengaruh salah satu elite desa lebih besar daripada elite lainnya. Kedua, pola interaksi saling menjaga untuk tidak saling mengganggu di antara para elite desa (Bahar, 2014).

Pada observasi awal di lokasi penelitian, terlihat pemerintah desa Jelgung secara langsung melibatkan para elite desa yang memiliki pengaruh yang kuat untuk menjadi anggota tim Satuan Tugas dan membantu tim relawan COVID-19. Tingkat partisipasi warga Desa Jelgung juga dipengaruhi oleh reputasi kepala desa yang turut berkontribusi terhadap penanggulangan Pandemi COVID-19 (Endik Hidayat, 2021). Entitas kepala desa sebagai pemimpin wilayah pedesaan dan bagaimana kelompok atau aktor elite mampu mendorong warga desa masih menjadi pertanyaan selama observasi berlangsung (Riauan et al., 2020). Kelompok elite juga mendapatkan penghormatan yang tinggi dan menempati struktur sosial puncak piramida dalam masyarakatnya. Besarnya pengaruh sosok elite menjadi tokoh sentral dalam perubahan suatu masyarakat dan pengembangan masyarakat (Zamroni, 2007). Pembentukan posko tim relawan penanganan COVID-19 membutuhkan partisipasi elite desa. Kepala desa menjelaskan akan sulit membendung wabah penyakit tanpa peran dari tokoh-tokoh 
masyarakat dalam tim relawan percepatan penanggulangan pandemi COVID-19. Sebagai gambaran awal desa Jelgung hanya memiliki sumber daya terbatas untuk operasional relawan yang diambil dari dana desa sebesar Rp. 15 Juta. Jumlah tersebut terlalu kecil untuk keperluan logistik 12 posko yang berdiri di pelosok desa dan dibantu tiga puluh (30) orang relawan.

Di desa Jelgung mayoritas penduduk beragama Islam sehingga desa ini mempunyai identitas muslim yang cukup kuat. Identitas budaya ini dibutuhkan dalam setiap wilayah untuk menciptakan lingkungan wisata kepada pengunjung (Gandakusumah \& Marta, 2021). Hal ini terlihat dari menjamurnya beberapa pondok pesantren berada di sekitar kecamatan Robatal. Salah satu upaya mitigasi pandemi COVID-19 dari pemerintah desa adalah menggandeng kelompok elite agama untuk menunda dulu kegiatan perayaan keagamaan bagi kalangan pesantren karena kegiatan berpeluang besar terjadi titik kumpul massa di desa Jelgung. Tokoh agama memotret realitas kultural masyarakat desa Jelgung selama penanggulangan pandemi (Fauzi \& Fasta, 2020). Dalam hal ini kelompok elite agama tersebut diwakili oleh kiai pengasuh pondok pesantren, guru mengaji, dan ustaz. Pesan verbal maupun non-verbal dalam tokoh desa dapat mendorong perilaku masyarakatnya (Lumampauw et al., 2021). Kepatuhan orang Jawa dan Madura kepada pemimpin agama, politik, dan ekonomi yang relatif tanpa sikap kritik dan kontrol menyebabkan penyebaran agama Islam berjalan dengan mulus tanpa ketegangan. Kepatuhan atau yang disebut Manut dalam Jawa berkaitan erat dengan kebudayaan Jawa sesuai dengan tata krama masyarakat Jawa yang telah dianut sejak lama (Adab et al., 2013). Fenomena ini terjadi mengingat para wali sendiri biasanya juga merupakan elite politik dan elite ekonomi yang mampu menembus relung-relung kebudayaan komunitas masyarakat Madura (Al Humaidy \& Ariwidodo, 2020). Kepercayaan akan tokoh elite dalam merepresentasikan masyarakat Madura secara keseluruhan juga memiliki peran tersendiri terhadap kepatuhan anggota masyarakat (Sari et al., 2021).

Beralih pada sektor kegiatan ekonomi desa, berdasarkan data pemerintah desa, maka pendapatan utama masyarakat desa Jelgung adalah di bidang pertanian, yaitu mayoritas pekerjaannya adalah petani (231 orang), buruh tani (1.012 orang), dan pemilik usaha tani sebanyak 617 orang. Permasalahan ekonomi dan kesejahteraan yang timbul di pedesaan akibat pandemi COVID-19 adalah masalah kemiskinan, yakni warga desa yang kehilangan pendapatan karena pemutusan hubungan kerja dan lesunya aktivitas bisnis. Kemiskinan merupakan masalah yang harus diselesaikan oleh pemerintah, terutama masalah kemiskinan yang ada di desa. Salah satu cara yang telah diupayakan oleh pemerintah desa untuk pengentasan kemiskinan yang berada di desa adalah dengan melakukan penguatan ekonomi desa dengan mengkonsolidasikan elite ekonomi lokal dan Badan Usaha Milik Desa (BUMDes) untuk menyerap tenaga kerja dari penduduk desa Jelgung. Kasus ini menunjukkan peranan kelompok elite desa dalam menata pola interaksi dengan warga desa untuk tetap mematuhi kebijakan pemerintahan dalam rangka memutus rantai penyebaran COVID-19.

Tabel 1. Gambaran Desa Jelgung Kabupaten Sampang

\begin{tabular}{lll}
\hline No & \multicolumn{1}{c}{ Profil Desa } & \multicolumn{1}{c}{ Keterangan } \\
\hline 1 & Penduduk Laki-laki (2018) & 4.861 Orang \\
2 & Penduduk Perempuan (2018) & 1.803 Orang \\
3 & Agama Mayoritas & Islam \\
4 & Mata Pencaharian $\quad$ Sektor & 231 Petani \\
& Pertanian & \\
\hline
\end{tabular}




\begin{tabular}{lll}
\hline & & 1.102 Buruh Tani \\
& & 617 Pemilik Usaha Tani \\
3 & Posko COVID-19 & 12 Pos \\
4 & Tim Relawan COVID-19 & 30 Orang \\
5 & Dana Operasional Relawan & Rp. 15 Juta/per bulan \\
\hline
\end{tabular}

Sumber: Kompilasi Penulis

Pembahasan tentang kelompok elite desa identik kelompok masyarakat yang disegani, dihormati, kaya serta berkuasa, strata, memiliki kemampuan mengendalikan aktivitas perekonomian dan sangat dominan mempengaruhi proses pengambilan keputusan-keputusan penting. Itulah sebabnya, mudah dimengerti apabila dalam banyak hal kelompok elite tidak hanya ditempatkan sebagai pemberi legitimasi, tetapi lebih dari itu mereka adalah panutan sikap dan acuan tindakan, serta senantiasa diharapkan dapat berbuat nyata bagi kepentingan bersama (Fargomeli, 2014). Kemudian kelompok lain yang didominasi oleh elite disebut massa. mereka adalah mayoritas inferior, yang posisinya dalam stratifikasi masyarakat berada di bawah, tidak memiliki kemampuan mengendali baik kegiatan dalam bidang ekonomi maupun politik, serta dorman dalam proses pengambilan keputusan-keputusan krusial (Usman, 1990).

Berdasarkan latar belakang pembahasan tentang elite desa, sehingga pertanyaan yang muncul dalam artikel ini adalah untuk dapat mengidentifikasi siapa saja yang menjadi kelompok elite di desa Jelgung selama situasi pandemi COVID-19. Berpijak pada pertanyaan siapa yang disebut kelompok elite, Putnam (1976) menganjurkan untuk menggunakan analisis posisi, reputasi, dan keputusan. Analisis posisi mendudukkan elite sebagai pihak yang strategis dalam struktur, mereka sosok yang paling dominan dalam keputusan yang menentukan nasib masyarakat. Analisis reputasi mendudukkan elite sebagai pihak berpengaruh terhadap keputusan politik, walaupun mereka tidak berada dalam ranah kekuasaan birokrasi. Terakhir analisis keputusan ketika elite memiliki pengaruh dalam organisasi sebagai upaya pendapat dan gagasan dapat dijadikan rujukan bagi keputusan urusan publik. Ketiga perangkat analisis ini berlaku bagi usaha mengidentifikasi elite dalam berbagai domain dari aras nasional, regional maupun lokal. Pada lingkup desa, wilayah beroperasinya elite tersebut dikenal dengan politik lokal. Tetapi meskipun dominasi perannya memang di tingkat lokal, di beberapa negara bahkan elite politik lokal ini dapat saja memiliki peran yang signifikan di tingkat negara atau supradesa (Azizah, 2013).

Artikel ini menggunakan dua teori utama, yaitu teori elite yang sudah dipaparkan di atas dan teori sumber kekuasaan. Penggunaan teori sumber daya kekuasaan relevan dalam konteks mendeskripsikan gambaran konfigurasi elite desa. Teori Andrain (1992) membagi sumber daya menjadi lima komponen. Pertama, sumber daya fisik. Sumber daya fisik ini dapat muncul dalam bermacam bentuk, seperti kepemilikan senjata dan instrumen kekerasan lainnya. Kedua, sumber daya ekonomi. Sumber daya ekonomi berupa kekayaan, sumber pendapatan atau juga berupa kekuatan untuk mengontrol barang/jasa yang dibutuhkan masyarakat. Ketiga, sumber daya normatif. Sumber daya yang berdasarkan kebenaran moral, kebenaran tradisi, legitimasi dan kebenaran agama. Dengan sumber daya ini, seseorang dapat menghukum benar atau salah, baik atau buruk serta patut atau tidak patut dari sebuah perbuatan. Sumber daya normatif hanya dapat dimiliki oleh seorang yang memiliki kualifikasi moral, mereka telah diakui oleh masyarakat secara masif sebagai sosok yang tepat sebagai posisi penjaga moralitas. Keempat, sumber daya personal. Sumber daya mengacu pada kualitas seseorang atau 
pribadi yang memperoleh dukungan dan pengakuan dari masyarakat. Dukungan dari masyarakat menjadi sebuah ukuran atau gambaran akan kualitas pribadi seseorang. Seperti karisma yang dimiliki seseorang, sehingga masyarakat menjadi tertarik untuk patuh dan memberikan dukungan kepada seseorang tersebut. Kelima, sumber daya keahlian. Sumber daya seseorang atas pengetahuan, informasi atau ketrampilan teknis lainnya. Dengan sumber daya ini seseorang memiliki nilai lebih dibandingkan orang lain. Artikel ini berusaha menemukan kebaruan empiris dengan sengaja penelitian ini dilakukan pada masa pandemi COVID-19 terutama fokus memotret konfigurasi elite di desa Jelgung.

Peneliti telah menelaah sejumlah penelitian terdahulu terkait kelompok elite desa di Indonesia. Salah satu penelitian yang dilakukan oleh Prastiwi (2016) menunjukkan adanya penjembatanan peran tokoh agama pesantren di Madura sebagai pendidik keagamaan dengan penengah politik. Keserupaan pergeseran peran politik pada kaum elite desa juga terdapat pada penelitian yang telah dikaji oleh Romadlon (2016) di mana terdapat kesenjangan kuasa dari pemerintahan pusat dengan pemerintahan daerah sehingga sejumlah tokoh daerah harus menengahi kebijakan pemerintah pusat. Implikasi pergeseran peran kekuasaan elite daerah juga ditemukan dalam penelitian Harianto (2016) di mana pelantikan kepala desa baru dapat mengubah infrastruktur desa secara keseluruhan. Konversi tersebut didasari oleh kepribadian kepala desa yang tidak memandang kelompok masyarakat desa yang berbeda dan menyetarakan derajat seluruh warga desa.

Kontribusi kelompok elite desa juga tampak dalam penelitian Mantrawan (2016) di mana program Musrembang rujukan kelompok elite menjadi jembatan negosiasi politik dengan infrastruktur warga Desa Blahbatuh. Pertanyaan yang menggelitik peneliti adalah apakah fenomena pandemi maka terjadi perubahan elite dan pergeseran elite di tingkat desa. Rasa keingintahuan tersebut menjadi peluang gap (celah) tersebut belum terjawab dari sejumlah studi sebelumnya. Selanjutnya, untuk lebih menunjukkan perbedaan artikel ini dibandingkan studi lainnya maka berikutnya dipaparkan beberapa penelitian tentang elite desa yang sudah pernah dilakukan sebelumnya. Perubahan struktur politik pasca reformasi memberikan dampak dalam kategori desa. Otonomi daerah memberikan porsi kekuasaan dalam desa yang terlihat alam kelompok atau aktor elite desa, seperti Badan Perwakilan Desa (Cahyono, 2005). Pergeseran elite politik dan orang kuat lokal di pemilihan kepala desa. Proses terlibatnya orang kuat lokal yang terdiri dari preman kampung (blater), tokoh agama kiai, para ustaz, serta elite politik lokal di luar desa dari pemerintahan eksekutif dan legislatif tingkat kabupaten (Pribadi, 2015).

\section{Metode}

Studi desa Jelgung Kabupaten Sampang ini menggunakan metode kualitatif dengan model penelitian studi kasus. Alasan memilih desa Jelgung adalah untuk kemudahan dalam pengumpulan data karena situasi pandemi COVID-19, serta peneliti sudah mengenal pihak kepala desa Jelgung. Untuk mengelaborasi detail konfigurasi elite desa Jelgung selama masa pandemi COVID-19, maka model penelitian studi kasus relevan untuk mengurai rumusan masalah kasus ini. Menurut Mars \& Stoker (2010), metode kualitatif bertujuan untuk mengeksplorasi pengalaman subjektif orang dan makna yang dapat dihubungkan dengan pengalaman-pengalaman lain. Metode kualitatif juga baik untuk menelisik ke dalam pemikiran proses atau narasi yang dikonstruksi oleh masyarakat. Metode ini memberi perhatian khusus pada isu-isu kontekstual, menempatkan sikap dan perilaku terwawancara dalam konteks biografi pribadi mereka dan latar sosial yang lebih luas (Khakim et al., 2020). Konteks dalam perilaku 
narasumber dalam penelitian kualitatif terdapat dalam fenomena komunikasi yang tercipta melalui pola komunikasi kelompok elite desa dengan warga Desa Jelgung.

Dalam artikel ini digunakan dua sumber data, yakni data primer dan data sekunder. Pengumpulan data primer dilakukan melalui teknik wawancara mendalam dengan para informan yang relevan dengan topik elite desa. Pemilihan informan dilakukan dengan teknik informan bertujuan atau purposive (Moleong, 2011). Informan kunci terdiri dari narasumber berinisial HAH sebagai kepala desa Jelgung dan MZ, SM dan KN sebagai tokoh masyarakat. MZ terlibat dalam aktivitas sekretariat Desa Jelgung, SM bertugas mengelola BUMD, sementara KN merupakan tokoh NU Desa Jelgung. Terdapat pula dua narasumber sebagai Kepala Dusun berupa SW selaku Kasun Tarogen dan JZ sebagai Kasun Bereksabe. Data dari informan kunci diperkuat dengan data sekunder, seperti berita seputar penanggulangan virus Covid-19 desa Jelgung di berbagai media online, dokumentasi, dan studi pustaka. Sedangkan pada tahap analisis data, artikel ini menggunakan prosedur dengan tahapan-tahapan sebagai berikut: (1) pengumpulan data melalui literatur dan dokumen media elektronik; (2) klasifikasi data; (3) transkrip rekaman hasil wawancara; (4) pengaturan data yang telah diidentifikasi; (5) anonim data yang sensitif seperti informasi pribadi; (6) koding data; (7) identifikasi tema; (8) pengkodingan ulang; (9) pengembangan kategori dan tema; (10) menghubungkan fakta empiris dengan teori; (11) penulisan laporan hasil penelitian (Horison, 2016).

\section{Hasil dan Pembahasan}

Salah satu faktor keberhasilan Sampang menyandang status zona hijau dibandingkan daerah lainnya adalah pemerintah desa yang bergerak cepat mengimplementasikan kebijakan pencegahan penyebaran COVID-19. Bagian ini membahas tentang bagaimana terbentuknya pengaruh elite desa ditinjau dari kepemilikan sumber kekuasaan, saluran kekuasaan elite desa, dan dampak pandemi terhadap sumber kekuasaan elite desa. Kelompok elite desa mengelaborasi alasan terbentuknya sebuah kekuasaan. Peranan kelompok elite juga dijelaskan dalam proses wawancara untuk memahami saluran kekuasaan dalam desa. Sumber kekuasaan adalah komponen penting dalam menentukan kuat atau lemahnya pengaruh dan peranan elite desa dalam interaksi dengan masyarakat desa. Kontribusi peranan elite desa tersebut ditentukan oleh kemampuannya dalam menghimpun sumber-sumber kekuasaan.

\section{Sumber dan Saluran Kekuasaan Kelompok Elite Desa Jelgung}

Elite desa harus memiliki nilai-nilai ciri kepribadian yang diakui dan dihormati oleh masyarakat. Kredibilitas terbukti menjadi prasyarat bagi elite untuk meraih jabatan politik di desa. Oleh sebab itu, terdapat dua faktor pembentukan elite melalui penguasaan sumber daya, yaitu latar belakang sejarah masyarakat dan struktur sosial (Hudayana, 2011).

Elite desa harus dapat menguasai satu atau beberapa sumber daya pengaruh, dan memosisikan status sosial lebih tinggi daripada golongan massa tingkat desa (E Hidayat, 2018). Di desa Jelgung beberapa sumber kekuasaan mendapat penghargaan yang tinggi selama pandemi COVID-19. Pertama, elite kesehatan sebagai orang yang terlibat dalam program kesehatan di posko pelayanan COVID-19 tingkat desa. Tenaga kesehatan desa terdiri dokter, bidan desa, dan perawat. Mereka memiliki sumber pengetahuan dan ketrampilan bidang kesehatan. Pandemi COVID-19 memberi peran penting dari peningkatan penghargaan dari masyarakat desa, yakni dengan memandang tinggi ilmu pengetahuan dan pendidikan bidang kesehatan. 
Kedua, elite birokrasi desa sebagai sumber kekuasaan berbasis status dan jabatan formal. Formal diartikan sebagai kelompok elite yang berkuasa atau memegang pemerintahan di desa Jelgung. Pemerintah desa terdiri dari kepala desa, perangkat desa, dan Badan Permusyawaratan Desa (BPD). Kekuasaan formal mempunyai otoritas mengambil keputusan penting dan langkah-langkah konkret yang harus dieksekusi secara cepat supaya bisa menghambat penyebaran virus, dan menjaga keamanan desa dalam konteks pandemi COVID-19.

Ketiga, Elite agama sebagai pemegang otoritas keagamaan. Sosok kiai dan tokoh pesantren layak menempati jajaran elite dalam struktur masyarakat desa Jelgung. Elite agama harus memiliki sumber kekuasaan pengetahuan agama yang luas agar diakui sebagai pemimpin karismatik yang disegani. Di desa Jelgung dikenal beberapa gelar elite agama. Kiai biasanya dibantu elite agama lainnya, seperti ustaz (laki-laki) dan ustazah (perempuan) - sebutan guru yang mengajar agama Islam. Peran pemuka agama sebagai pembentuk opini publik dibutuhkan dalam rangka sosialisasi ancaman bahaya penyebaran virus COVID-19 di desa Jelgung. Posisi elite agama, menjadikannya sebagai sumber referensi bagi masyarakat sekitar. Para tokoh agama bukan hanya mengajarkan agama, tetapi juga memberi dukungan kepada pemerintah desa maupun masyarakat dalam menjalankan protokol kesehatan di lingkungan pesantren maupun wilayah desa.

Kempat, elite blater yang identik dengan kelompok jawara. Sumber kekuasaan blater ditentukan oleh beberapa kategori, bisa kekayaan yang dimiliki; kemampuan mengorganisir kejahatan seperti pencurian dan perampokan; kekuatan jaringan yang dimiliki; kehebatan menghindar dan selamat dari pihak keamanan; pengalaman dalam dunia hitam (premanisme); dan terakhir kesaktian berupa keahlian dalam bela diri (Bahar, 2014). Sejarah sosial desa Jelgung, menurut pengakuan informan wilayah Kecamatan Robatal, merupakan salah satu daerah yang rawan tindakan kejahatan di pulau Madura. Eksistensi kelompok blater identik dengan posisi antagonis di masyarakat desa Jelgung sehingga keberadaan kelompok ini pada sebuah wilayah desa menjadi ancaman bagi keamanan warga desa. Sebutan blater lebih dominan mengandung konotasi negatif, kelompok preman, jago berkelahi, dan tindakan kejahatan.

Kelima, elite ekonomi berbasis kepemilikan aset kekayaan materi. Sumber materi ini bisa berwujud tanah yang luas, bangunan megah, dan benda-benda berharga lainnya seperti mobil atau emas lainnya. Sesuai dengan kondisi desa Jelgung yang merupakan desa pertanian dan agribisnis, para tuan tanah memiliki posisi strategis dalam struktur masyarakat. Dengan demikian, posisi kepala desa dan perangkat desa, termasuk individu pemilik tanah cukup luas, karena mereka mendapat hak mengelola tanah aset desa (bengkok). Selain tuan tanah, kelompok wiraswasta desa Jelgung muncul sebagai elite ekonomi yang dipandang mempunyai keahlian bisnis dan mampu secara finansial. Kelompok pemilik modal ini dibutuhkan oleh masyarakat desa untuk membuka lapangan kerja di tingkat desa. Karena situasi pandemi COVID-19 berdampak kepada beberapa warga desa yang kehilangan pekerjaan dan tidak punya pendapatan.

Keenam, elite militer mempunyai kedudukan yang kuat dan disegani oleh masyarakat desa Jelgung. Kelompok ini memiliki sumber kekuasaan berasal dari status pekerjaan dan organisasi militer. Adanya kebanggaan dan keterikatan pada organisasi militer, maka kelompok ini terdiri dari tentara masih aktif dan para purnawirawan Tentara Nasional Indonesia (TNI). Elite militer selalu diundang dalam 
setiap rapat desa, semisal melaksanakan semua keputusan pencegahan pandemi dan implementasi kebijakan protokol kesehatan secara konsisten.

Tabel 2. Elit Desa Perspektif Sumber dan Saluran Kekuasaannya

\begin{tabular}{|c|c|c|c|}
\hline No & Elit Desa & Sumber Kekuasaan & Saluran Kekuasaan \\
\hline 1 & Birokrasi & $\begin{array}{l}\text { Kekuasaan Formal } \\
\text { Supradesa }\end{array}$ & Pemerintah Desa \\
\hline 2 & Agama & $\begin{array}{l}\text { Kekuasaan Spiritual } \\
\text { Agama }\end{array}$ & $\begin{array}{l}\text { Pesantren, Majelis } \\
\text { Pengajian }\end{array}$ \\
\hline 3 & Kesehatan & $\begin{array}{l}\text { Ketrampilan Bidang } \\
\text { Kesehatan }\end{array}$ & $\begin{array}{l}\text { Posko Klinik Desa, } \\
\text { Puskesmas }\end{array}$ \\
\hline 4 & Blater & $\begin{array}{l}\text { Ilmu bela diri dan } \\
\text { Jaringan Preman }\end{array}$ & $\begin{array}{l}\text { Kelompok Jawara dan } \\
\text { Bejingan }\end{array}$ \\
\hline 5 & Ekonomi & $\begin{array}{l}\text { Kekayaan dan } \\
\text { Materi }\end{array}$ & $\begin{array}{l}\text { Unit Usaha Desa, Pemilik } \\
\text { Tuan Tanah }\end{array}$ \\
\hline 6 & Militer & $\begin{array}{l}\text { Organisasi Militer } \\
\text { dan Kepangkatan } \\
\text { Pekerjaan }\end{array}$ & $\begin{array}{l}\text { Koramil, Posko Pengaman } \\
\text { Desa }\end{array}$ \\
\hline
\end{tabular}

Sumber: Olahan Penulis

Pada Tabel 2 di atas, yang dimaksud saluran kekuasaan adalah media atau sarana yang digunakan elite desa untuk berinteraksi dan menyalurkan pengaruhnya kepada masyarakat. Saluran ini dapat berupa lembaga, organisasi, proyek pembangunan, dan kegiatan kemasyarakatan. Kekuasaan yang digunakan oleh elite berpengaruh pada kedalaman dan luasnya jangkauan pengaruh terhadap masyarakat desa (Sugiyanto, 2021). Pada desa Jelgung saluran kekuasaan yang diaktualisasikan elite desa terdiri dari pusat layanan kesehatan (Posko COVID-19) di desa, Puskesmas, Polindes, lembaga pendidikan pesantren, pengajian majelis Taklim, organisasi militer, lembaga pemerintahan desa, unit bisnis desa (swasta dan BUMDes), dan perkumpulan jawara (ormas) atau persatuan blater. Dari beberapa saluran kekuasaan tersebut, Romadhon (2017) menjelaskan perbedaan antara saluran kekuasaan bersifat formal (dalam bentuk organisasi resmi) dan bersifat tidak resmi atau informal. Sebagai contoh, organisasi formal terdiri dari organisasi layanan kesehatan, organisasi pemerintah desa, organisasi militer, dan lembaga-lembaga pendidikan pesantren. Sedangkan organisasi nonformal atau tidak resmi terdiri dari kelompok pengajian dan kelompok preman.

\section{Analisis Posisi dan Reputasi Elite dalam Keputusan Desa Jelgung}

Saat orde baru berkuasa, elite desa yang didominasi pensiunan tentara mempunyai peran dan kewenangan yang besar dalam kehidupan sosial dan politik di pedesaan. Pergeseran politik pasca reformasi mengubah struktur politik dalam wilayah desa. Kalangan elite dalam desa bergeser dari kelompok militan menjadi kelompok sipil dalam pergeseran struktur. Dominasi tersebut lebih menitikberatkan pada bentukbentuk dominasi dan dinamika sosial yang terjadi dalam hubungan antara mereka yang memiliki kekuasaan dan yang tidak memiliki kekuasaan. Ada tiga dimensi yang dapat dijadikan dasar kekuasaan untuk membentuk kekuasaan, yaitu ekonomi, kekuasaan politik dan status. Penekanannya terletak pada struktur kekuasaan. Mereka yang menduduki posisi atas dalam institusi masyarakat yang penting membentuk elite kekuasaan yang terintegrasi dan terpadu, berupa keputusan-keputusan penting untuk menentukan struktur dasar dan arah masyarakat (Johnson \& Lawang, 1994). 
Artikel ini berusaha mengetahui siapa dan kelompok mana saja yang berpengaruh selama pandemi COVID-19 di desa Jelgung. Adapun untuk menjawab permasalahan tersebut maka dapat digunakan tiga analisis sesuai dengan teori elite, yaitu analisis posisi, reputasi, dan keputusan. Untuk analisis posisi, seseorang elite atau kelompok mempunyai kekuasaan apabila ia atau mereka menduduki jabatan tinggi atau penting dalam pemerintahan desa. Untuk mengetahui siapa yang menduduki jabatan tinggi dalam pemerintahan desa, bisa terlihat dalam struktur formal pemerintahan desa. Adapun perkembangan situasi pandemi pemerintahan desa Jelgung bergerak cepat dengan membentuk satuan tugas (Satgas COVID-19). Upaya ini bertujuan sebagai wadah para relawan untuk membendung penyebaran virus COVID-19 di desa.

Selain para relawan desa dari kalangan massa, posisi anggota Satgas COVID-19 juga beranggotakan tokoh-tokoh elite berpengaruh di desa Jelgung. Berdasarkan pengakuan informan, komponen utama Satgas COVID-19 adalah elite birokrasi, yaitu seorang kepala desa sebagai ketua dan seluruh perangkat desa otomatis menjadi anggota. Posisi kepala desa mempunyai kewenangan untuk mengatur dan mengurus keperluan desa atas inisiatif sendiri sesuai dengan keadaan dan kebutuhan desa. Kepala desa Jelgung memusatkan kegiatan pemerintahan dan pengawasan perkembangan COVID-19 dengan mendirikan posko di balai desa sebagai upaya membendung penyebaran COVID-19. Posko Satgas COVID-19 tersebut juga melibatkan tim relawan yang berasal dari petugas medis atau elite kesehatan. Posisi petugas kesehatan memiliki nilai-nilai yang dipandang tinggi oleh masyarakat desa karena kepandaian dan keterampilan dalam bidang kesehatan masyarakat. Posisi ini sangat strategis pada masa pandemi COVID-19 sehingga petugas kesehatan memiliki sumber daya berupa ilmu pengetahuan dari jenjang pendidikan formal yang dilalui pada bidang kesehatan. Pada kasus desa Jelgung beberapa elite yang dilibatkan adalah tenaga medis yang terdidik sebagai petugas kesehatan desa seperti dokter, perawat, dan bidan desa.

Analisis reputasi adalah unit teori untuk mengidentifikasi pihak yang berkuasa yang tidak didasarkan pada bagan organisasi formal, tetapi pada reputasi kekuasaan mereka secara informal. Teknik ini memberikan kekuasaan kepada aktor elite desa yang belum memiliki jabatan resmi namun memiliki kontribusi baik langsung maupun tidak langsung (Yuningsih \& Subekti, 2016). Dalam kultur Madura, reputasi kiai dan blater adalah tokoh elite yang memiliki pengaruh besar pada masyarakat desa, tetapi tidak tercantum dalam struktur organisasi formal pemerintahan desa maupun anggota Satgas COVID-19. Misalnya, posisi kiai begitu penting bagi masyarakat Sampang dan desa Jelgung. Pengaruhnya bahkan bisa melebihi sosok orang tua bagi masyarakat yang memegang kultur Madura. Secara lebih khusus sosok kiai menjadi fenomena sosial yang kaprah.

Dalam tradisi Madura, yang kemudian juga diadopsi serta diterima masyarakat Sampang, semboyan buppa babu dan guruh-ratoh betul-betul menjadi prinsip hidup. Eksistensi guru (kiai) diletakkan lebih tinggi daripada seorang penguasa dalam konteks sosial. Sebagai sumber legitimasi agama, kiai pantas mendapat posisi sebagai elite pada struktur masyarakat pedesaan, khususnya desa yang memegang tradisi santri yg kuat. Bagi golongan santri, reputasi kiai bukan hanya sekedar guru agama yang berkewajiban mengajar dan mendidik mereka. Namun, kiai dianggap sebagai penerus perjuangan para nabi sehingga wajib dihormati dan diikuti pendapatnya (Kosim, 2012).

Sosok kiai berbeda dengan elite blater. Jika kiai identik dengan sumber kekuasaan berbasis spiritual, blater identik dengan sumber berbasis kekerasan. Sebagai contoh sumber kekuasaan blater adalah ketangkasan ilmu bela diri untuk adu fisik, keberanian, kepribadian, dan kemenangan dalam setiap perkelahian fisik atau dalam 
budaya Madura disebut carok (Marta, 2017). Elite blater semakin disegani masyarakat desa apabila memiliki riwayat terlibat kriminalitas dan aksi kekerasan. Reputasi blater menentukan aman atau tidaknya desa dari aksi kejahatan pencurian dan perampokan. Ketika blater melepas peran sebagai penjaga keamanan desa, maka kemungkinan keamanan desa pasti tidak terwujud. Kosim (2012) menjelaskan gerombolan penjahat akan berpikir sepuluh kali untuk mengacau sebuah desa yang ditinggali seorang blater. Apalagi jika blater tersebut tergolong papan atas. Berbekal komitmen melindungi harta dan kehormatan untuk tidak saling mengganggu antara sesama blater, wilayah desa menjadi semakin aman.

Untuk menentukan elite desa Jelgung berdasarkan analisis reputasi, studi ini menemukan dua cara. Pertama, melalui penelusuran sejarah dan kultur, tujuannya mengetahui reputasi apa dianggap figur menonjol bagi masyarakat desa Jelgung. Kedua, analisis reputasi melalui keanggotaan dari lembaga-lembaga desa semisal relawan COVID-19, RT, RW, dan Karang Taruna. Organisasi tersebut tidak termasuk dalam struktur organisasi formal pemerintahan desa, tetapi secara tidak langsung mempunyai pengaruh terhadap jalannya pemerintahan desa. Selama pandemi COVID-19, pihak otoritas desa Jelgung melibatkan kelompok blater jika terjadi konflik-konflik sosial di masyarakat akibat berbagai kebijakan pencegahan COVID-19. Misalnya, pihak desa melarang adanya hajatan warga desa yang berpotensi terjadinya kerumunan massa; sosialisasi kepada warga untuk memakai masker; pelarangan mudik bagi warga desa Jelgung yang tinggal di luar Sampang; dan sanksi bagi warga desa yang terbukti melanggar protokol kesehatan di desa Jelgung.

Dalam rangka penerapan berbagai kebijakan pandemi tersebut, sering kali ada warga yang tidak patuh protokol kesehatan dan tetap melanggar anjuran untuk tidak berkumpul dengan jumlah banyak. Pelanggaran protokol kesehatan ditindak tegas oleh tim relawan desa Jelgung sebagai garda terdepan desa dalam upaya membendung penyebaran COVID-19, mereka sering kali berkonflik dengan warga desa yang terbukti melakukan pelanggaran. Dalam konflik tersebut, blater bisanya berperan sebagai mediator konflik antara tim relawan dengan warga desa. Peran mediasi berjalan dengan cukup efektif karena blater adalah sosok yang disegani dan ditakuti warga desa. Para blater berhasil mempertahankan posisi elite desa dengan berbagai bentuk, mulai dari cara-cara negatif seperti teror hingga cara-cara yang positif, seperti membantu warga desa, santun, punya empati sosial, dan membela keamanan desa. Status jawara melekat pada seorang blater sampai ia meninggal dan menjadi nama yang dikenang di desa Jelgung.

Terakhir untuk penentuan elite melalui analisis keputusan dapat terlihat siapa dan kelompok mana saja yang paling berpengaruh dalam proses pengambilan keputusan desa. Pembuatan keputusan dan kebijakan desa biasanya melalui rapat-rapat desa. Kepala desa Jelgung menjelaskan untuk keputusan penting diambil melalui mekanisme musyawarah desa (Musdes) yang melibatkan individu, kelompok, tokohtokoh masyarakat yang berasal dari kalangan elite dan massa. Secara umum pendapat elite desa lebih dominan daripada kalangan massa--walaupun perwakilan warga biasa juga diundang rapat-ketika terlibat dalam rapat pengambilan keputusan publik. Keputusan, menurut Surbakti (2010), mencakup keterikatan masyarakat dalam keputusan politik, pilihan alternatif dan prioritas terhadap kebijakan umum desa. Keputusan dapat diluncurkan melalui kekuasaan dan wewenang, namun dapat juga menggunakan teknik propaganda atau teknik koersif apabila terjadi pertentangan dalam kebijakan yang dirancang. 


\section{Kesimpulan}

Artikel ini menemukan terjadinya pergeseran sumber dan saluran kekuasaan selama pandemi COVID-19 terhadap konstelasi elite desa Jelgung. Kedudukan aktoraktor utama dalam dinamika perimbangan kekuasaan antar elite telah berubah akibat bergesernya dasar kekuasaan pada situasi pandemi. Sumber kekuasaan yang bertahan adalah dari institusi formal seperti elite birokrasi desa, institusi agama seperti kiai maupun guru mengaji, dan elite ekonomi sebagai kelompok wirausahawan desa. Sebaliknya di desa Jelgung sumber kekuasaan berasal kekuatan fisik seperti blater dan individu berasal organisasi militer berkurang pengaruhnya. Adapun sumber kekuasaan ketrampilan dan intelektualitas di bidang kesehatan meningkat pengaruhnya karena situasi darurat kesehatan dampak dari ancaman wabah penyebaran virus COVID-19. Masyarakat desa Jelgung mempunyai penghargaan pada kepribadian elite desa maupun kemampuan elite desa untuk terlibat memecahkan masalah-masalah kemasyarakatan selama pandemi COVID-19. Peningkatan pamor elite wilayah desa yang didukung tenaga kesehatan yang meredam penyebaran COVID-19 dan memperkuat posisi kelompok elite dalam memecahkan permasalahan daerah. Kapabilitas ini menjadi model kekuasaan aktor desa selama masa pandemi.

Sebagaimana dijelaskan sebelumnya, situasi pandemi memunculkan elite baru yang memiliki pengaruh besar yakni para tenaga kesehatan desa yakni dokter, perawat, dan bidan desa. Berdasarkan teori elite Putnam (1976), maka yang disebut elite desa selain orang-orang yang menduduki jabatan-jabatan resmi dan utama, juga aktor-aktor yang tidak menduduki jabatan resmi tetapi mempunyai kekuasaan cukup besar. Selain itu aktor-aktor ini memiliki pengaruh tak langsung, tetapi nasehat dan pendapatnya diperhatikan oleh pembuat keputusan. Artikel ini melihat hasil analisis posisi, reputasi, dan keputusan. Dapat diambil kesimpulan bahwa yang termasuk kategori elite di desa Jelgung adalah kepala desa beserta perangkat desa, kiai, tenaga medis desa, wirausahawan desa, kelompok purnawirawan TNI dan tentara aktif, dan kelompok jawara biasa disebut blater. Artikel ini mengkonfirmasi teori sumber kekuasaan Andrain (1992) bahwa kedudukan elite dipengaruhi sumber daya yang dimiliki semisal kekayaan, pekerjaan, organisasi, dan pendidikan. Perubahan menarik lain dari fenomena desa Jelgung adalah meningkatnya peranan elite dalam proses pengambilan keputusan desa, khususnya berbagai kebijakan terkait pandemi COVID-19. Secara empiris, pemerintah desa menggandeng kelompok elite untuk berkolaborasi menjaga keselamatan dan keamanan desa Jelgung.

\section{Referensi}

Adab, G., Rahma, A., \& Yuwono, S. (2013). Bahagiakah Kalau Manut? : Studi Perilaku Kepatuhan pada Masyarakat Jawa. Seminar Nasional Psikologi UMS 2013, 1(1), 407414.

Al Humaidy, M., \& Ariwidodo, E. (2020). The Symbolic Interaction of Tandhe'in Sumenep Madurese. KARSA: Journal of Social and Islamic Culture, 28(1), 172-191.

Andrain, C. (1992). Kehidupan Politik dan Perubahan Sosial. Yogyakarta: Tiara Wacana.

Azizah, N. (2013). Artikulasi politik santri: dari kyai menjadi bupati. Pustaka Pelajar bekerjasama dengan STAIN Jember Press.

Bahar, M. (2014). Kiyai and Bejingan: Local Political Elite and Hegemonic Culture. JICSA (Journal of Islamic Civilization in Southeast Asia), 3(1).

Basri, A. (2020). Tanggulangi Covid-19, Bupati Imbau Optimalkan Penggunaan DD.

Cahyono, H. (2005). Konflik elite politik di pedesaan: Relasi antara badan perwakilan desa dan pemerintah desa. Jurnal Penelitian Politik, 2(1), 73-84.

Fargomeli, F. (2014). INTERAKSI KELOMPOK NELAYAN DALAM MENINGKATKAN 
TARAF HIDUP DI DESA TEWIL KECAMATAN SANGAJI KABUPATEN MABA HALMAHERA TIMUR. ACTA DIURNA KOMUNIKASI, 3(3).

Fauzi, E. P., \& Fasta, F. (2020). Modern Muslimah in Media : A Study of Reception Analysis in " Saliha " Program on NET TV. ASPIRATION, 1(November), 135-162. http://www.aspiration.id/index.php/asp/article/view/19/28

Gandakusumah, B., \& Marta, R. F. (2021). Visualisasi Elemen Pembentuk Consumer Brandscape Melalui Oposisi Biner Semiotika Pemasaran Xing Fu Tang (幸福堂) Dan Xi Bo Ba (喜悦). Jurnal Bahasa Rupa, 4(2), 167-176. https://doi.org/10.31598/bahasarupa.v4i2.808

Hardhiyanti, Y., \& Rasyid, U. N. (2018). Komunikasi Bisnis Berbasis Etik Lingkungan sebagai CSR The Body Shop Indonesia. Bricolage: Jurnal Magister Ilmu Komunikasi, 3(02), 103-117. https://doi.org/10.30813/bricolage.v3i02.925

Harianto, H. (2016). Pergeseran Kekuasaan Elit Lokal di Desa Bontobulaeng Kecamatan Bulukumpa Kabupaten Bulukumba. UIN Alauddin Makassar.

Hidayat, E. (2018). Praktik Politik Oligarki dan Mobilisasi Sumber Daya Kekuasaan Di Pilkades Desa Sitimerto Pada Tahun 2016. JURNAL SOSIAL POLITIK, 4(2), 124-151.

Hidayat, Endik. (2021). Leadership of Village Chairman During The COVID-19 Pandemic Period in Jelgung Village, Robatal Distric, Sampang. Public Administration Journal of Research, 3(1).

Horison, L. (2016). Metodologi Penelitian Politik. Jakarta: Kencana Prenada Media Group. Hudayana, B. (2011). Glembuk, Strategi Politik dalam Rekrutmen Elite Penguasa di Desa Pulungansari Yogyakarta. Humaniora, 23(1), 1-15.

Johnson, D., \& Lawang, R. (1994). Teori sosiologi klasik dan modern. Gramedia Pustaka Utama.

Khakim, M. S., Nugraha, A. F., Sukanti, S., \& Sarwedi, A. R. (2020). Kontribusi Mahasiswa Daerah Dalam Penanganan Intoleransi Melalui Sinergi Perguruan Tinggi Di Diy. Jurnal Pendidikan Kewarganegaraan, 10(1), 62. https://doi.org/10.20527/kewarganegaraan.v10i1.8361

Kosim, M. (2012). Kyai dan blater (elite lokal dalam masyarakat Madura). KARSA: Journal of Social and Islamic Culture, 12(2), 149-160.

Lang, J. C. F., Marta, R. F., \& Menayang, A. P. (2020). Transformasi Identitas Kota Bitung Ditinjau dari Citra Pariwisata Heksagonal Anholt. Jurnal Riset Komunikasi, 3(2), 120-139. https://doi.org/10.38194/jurkom.v3i2.160

Lumampauw, A., Marta, R. F., Nugroho, Y., Sandel, T. L., \& Lie, S. (2021). The art of honing the conscience through bukalapak ads : barongsai Indonesia , juara hati membangun bangsa. International Journal of Visual and Performing Arts, 3(1), 9-21. https://doi.org/https://doi.org/10.31763/viperarts.v3i1.342

Magfirah, M., \& Saputra, R. (2021). Transmisi Pesan dan Pemrosesan Informasi Individu Menyoal Diskriminasi di Indonesia dari Perspektif Van Kaam. Expose: Jurnal Ilmu Komunikasi, 4(1), 34. https://doi.org/10.33021/exp.v4i1.1442

Mantrawan, I. P. W., Noak, P. A., \& Erviantono, T. (2016). Peran Elit Desa dalam Partisipasi di Tingkat Lokal dalam Perumusan Musrembang di Desa Blahbatuh Kabupaten Gianyar. Jurnal Politika Udayana, 1-8.

Mars, D., \& Stoker, G. (2010). Theory and Methods in Political Science (Teori dan Metode dalam llmu Politik). Bandung: Nusa Media.

Marta, R. F. (2017). Refleksi Hibriditas Budaya dalam Pancasila pada Realitas dan Media sebagai Identitas Bangsa. Bricolage: Jurnal Magister Ilmu Komunikasi, 3(01), 1-12. https://doi.org/10.30813/bricolage.v3i01.841

Moleong, L. J. (2011). Metodologi Penelitian Kualitatif, cetakan XXIX. In Bandung: PT. 
Remaja, Rosdakarya. Bandung: PT. Remaja Rosdakarya.

Muslim, A., Kolopaking, L., Dharmawan, A., \& Soetarto, E. (2015). Dinamika Peran Sosial Politik Ulama dan Jawara di Pandeglang Banten. MIMBAR: Jurnal Sosial Dan Pembangunan, 31(2), 461-474.

Prastiwi, M. I. (2016). POLITISASI PESANTREN DAN PERGESERAN FUNGSI PESANTREN DI MADURA. KARSA: Jurnal Sosial Dan Budaya Keislaman, 23(2), 208. https://doi.org/10.19105/karsa.v23i2.719

Pribadi, Y. (2015). The klebun, the kiai and the blater: notes from western Madura, Indonesia. South East Asia Research, 23(3), 303-317.

Riauan, M. A. I., Sari, G. G., Aziz, A., Prayuda, R., \& Sikumbang, A. T. (2020). Refleksi Anomali Makna Perilaku Merokok di Kalangan Dosen Universitas Islam Riau. Bricolage : Jurnal Magister Ilmu Komunikasi. https://doi.org/10.30813/bricolage.v6i02.2177

Romadhon, Y. (2017). Perubahan Politik di Desa: Implikasi Penetrasi Kapital Terhadap Hubungan Elite-Massa di Desa Diwek, Kecamatan Diwek, Kabupaten Jombang. Jurnal Politik Indonesia, 2(1), 103-110.

Romadlon, S. G. (2016). Implikasi Pergeseran Sistem Politik terhadap Hukum dan Birokrasi di Indonesia. Jurnal Konstitusi, 13(4), 868. https://doi.org/10.31078/jk1349

Sari, N., Marta, R. F., Angreani, N., Harry, H., \& Perkasa, M. I. A. (2021). Menakar Loyalitas Konsumen berdasarkan Persepsi Nilai dan Kepercayaan Merek Geprek Bensu. Soetomo Communication and Humanities, 2(2). https://ejournal.unitomo.ac.id/index.php/sch/article/view/4078

Sugiyanto, B. A. W. (2021). Hibriditas Budaya Jawa dan Budaya Barat di Museum Keraton Yogyakarta. Jurnal Ilmiah Multimedia Dan Komunikasi, 6(1), 1-11. http://ojs.mmtc.ac.id/index.php/jimk/article/view/107

Surbakti, R. (2010). Memahami Ilmu Politik. Jakarta: PT Gramedia Widiasarana Indonesia.

Usman, S. (1990). Elit dalam Perpsektif Sosiologi. Yogyakarta: Fakultas Ilmu Sosial dan Ilmu Politik UGM.

Varma, S. (2010). Teori Politik Modern. Jakarta: Rajawali Press.

Vicari, S., Iannelli, L., \& Zurovac, E. (2020). Political hashtag publics and countervisuality: a case study of \#fertilityday in Italy. Information Communication and Society. https://doi.org/10.1080/1369118X.2018.1555271

Yuningsih, N., \& Subekti, V. (2016). Demokrasi dalam pemilihan kepala desa? studi kasus desa dengan tipologi tradisional, transisional, dan modern di provinsi Jawa Barat tahun 2008-2013. Jurnal Politik, 1(2), 231-261.

Yusriyah, K., Fatoni, A., \& Mansyur, M. A. (2020). Communication Networks Analysis on Information Dissemination of the Moving of Capital City From Jakarta to East Kalimantan. ASPIRATION Journal.

Zamroni, I. (2007). Juragan, Kiai dan Politik di Madura. UNISIA, 30(65). 